\title{
Space Flexibility : A Design Concept for Accomodating Spatial Invasion in Communal Flat
}

\author{
Joshua Gama Wastara, Arina Hayati, and I Gusti Ngurah Antaryama \\ Department of Architecture, Institut Teknologi Sepuluh Nopember, Surabaya \\ e-mail:arina_h@arch.its.ac.id
}

\begin{abstract}
Housing needs are an urgent necessity for middle income residents in several areas in Surabaya. Thus, there are several dense settlements that were built illegally. The government provides the solution of simple rental flats (Rusunawa) as their substitute residence. Relocation of illegal settlement to rusunawa is often rejected by the inhabitant because oftentimes the design does not accommodate basic needs according to inhabitant's perceptual and subjective view. Space invasion as a lifestyle expression of informal settlement is often overlooked when designing a simple, low-cost apartment buildings (Rusunawa). The purpose of this study is to propose a flexible architectural concept, based on observations of space invasion exploration gathered from field studies. This study is initiated from an exploratory thinking which drives the formation of the architectural design-based research to determine the design issue, hypothesis and design mapping based on the method of conceptual design. Literature and precedent studies are obtained to propose the first hypothesis that will be applied and explored through field research investigation. The field study is conducted at the riverbank's settlement of Medokan Semampir Indah Tangkis Surabaya, which has a creative pattern and expression of space invasion. Our hypothesis states that spatial invasion activities are ways of expressing the lifestyle of people who live in riverbanks settlement. The Spatial invasion is expressed in domestic, social and economic activities. The results are then used as main idea or primary force for the concept design of collective residence, and to provide design criteria and parameters that suits to the needs and desires of the inhabitants.
\end{abstract}

Keywords-Invading Space, Flexible Space, Informal Settlement.

\section{INTRODUCTION}

$\mathrm{T}$ HE lifestyle of illegal village has indirectly influenced their style of settlement. It is based on the phenomenon of relocation refusal to communal residence (Das, 2015). For instance, the government always intend to relocate the illegal village inhabitants along the riverbanks towards a low income rental flat (Rusunawa). Nevertheless, the effort of the relocation of illegal inhabitants to Rusunawa is often ended up with a rejection. (Das, 2017). Rusunawa which is offered by the government has met the basic needs of inhabitants in the sense of privacy, utility and security (Hutagalung, 2004). Meanwhile, according to Maslow \& Lowery (1998) there are other needs that are more perceptual, subjective and specific to the desires of each person, including for inhabitants with lower middle needs. This underlies the question, whether the perceptual needs of inhabitants along the riverbanks can be used as a criterion for finding a settlement that can make them comfortable.
Space invasion is one of the lifestyle phenomena that is specific to the middle-lower settlement type (Lianto and Dwisusanto, 2015). This study is a part of a thesis based on design. The first step in exploring the issue is to questioning what invasion space is. Second, to find the criteria for communal residential design with the concept of flexibility. Exploration carried out to establish the concept of the design is not to determine the schematic design.

\section{THEORITICAL REVIEW}

According to Rapoport (2005), Lifestyle is taken from cultural syntax which contribute to a part of the cultural aspects. Lifestyle also influences and has relationships with other aspects of architecture such as time, usage, habitual settings, and the meaning of one's occupancy (Rapoport, 2005). Research conducted by Lianto and Dwisusanto (2015) showed that invading lifestyles also occurred in villages in Surabaya. Space invasion is still relatively common, as explained by Litanto that this invasion occurred in all villages in Surabaya.

According to Koesputranto (1988), physically the house is a shelter from outside human influences, such as climate, enemies, disease, and so on. However, housing has essential, subjective and perspectives (Frick and Mulyani, in the second series of Eco-Architecture, 2006). The concept of housing which is proposed in this study, is the concept of housing which coincide with the meaning of the housing itself for the research subject. The hypothesis can be deepened by exploration from field of observations and interviews to find out the significance of housing for residents. The exploration question in this hypothesis is: how to enable the main function of a house to accommodate the continuous growth of its inhabitants?

Flexibility in the low-cost rental flat is limited to the standards and conditions of each government. However, that does not mean Rusunawa cannot have a flexible design. Flexibility can be reflected as the form of interaction with its users, innovative and expressive towards the standard provisions in general. Development of life in terms of housing, requires a housing which can adapt to the development itself. The development referred here is proliferating, adapting to changes in life (Frick and Mulyani, 2006). Growth in housing is also a process of socialisation and adaptation to social norms.

The concept of flexibility responds to these needs. According to Kronenburg (2007) flexible buildings are 
The $6^{\text {th }}$ International Seminar on Science and Technology (ISST) 2020

July $25^{\text {th }} 2020$, Institut Teknologi Sepuluh Nopember, Surabaya, Indonesia

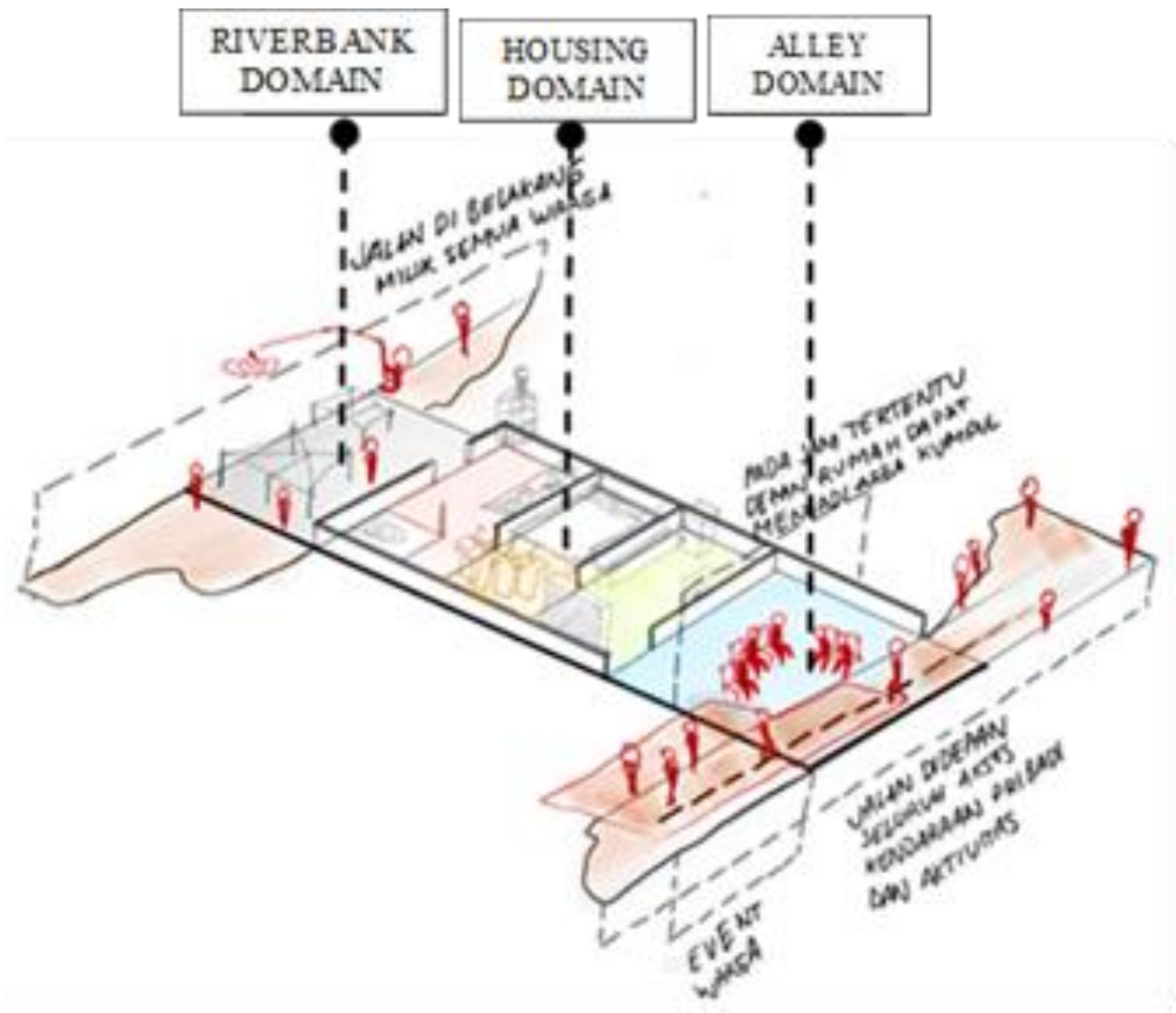

Figure 1. Diagram of domains and activities on the front road, back road, and area around the house.

intended to respond to situation changes in their usage, operation or location. Flexibility signifies the rejection of a standard idea on a standard (Hertzberger in Cetkovic Alexander, 2012). Although this flexibility means transformation in the sense of design, it does not mean that it is limited by mobile design or technology. Flexibility can be interpreted as interactions with users, innovative and expressive of contemporary design (Kronenburg, 2007). In this study, flexibility is following the observations of the people who interpret the house, and the mechanism of its space (invasion based). Flexibility is the result of the presentation of aforesaid mechanism.

\section{METODOLOGY}

This research explores issues, determines criteria, and formulates architectural concepts. As for the method used is based on design by research taken from the book written by Jormakka (2007). Exploring issues is supported by several data collection methods including observation and in-depth interviews. We use concept-based framework, considering the main hypothesis as the basic idea of architectural design which will be combined with data from field analysis. Literature studies and precedent studies are needed to establish evaluative hypotheses. Field studies are needed to find out how the expression of space invasion which is carried out would affect flexibility in the life of the residence. This study uses a behavioural architecture approach as the basis to formulate a critical point of view in designing a housing in accordance with the needs of a particular community. This approach emphasises the importance of understanding people or community in using their space (Haryadi Setiyawan, 2010).

Qualitative-based research to conduct research that is descriptive and uses analysis (Creswell, 2014). Design research is based on primary research into the design process, evolving from work in the design method, extending concepts to incorporate research into the design process. According to Plomp (2007) design research is a systematic study of designing, developing and evaluating educational interventions as solutions to solve complex problems in educational practice.

Based on the explanation of design research by Christopher Alexander in Jormakka (2007), design research in this study uses field studies to get more details on the intended invasion. Field studies require qualitative research such as interviews and empirical observations (Jormakka, 2007). Field studies and interviews are conducted to find out phenomena, expressions of the occupancy, and space invasions that occurred in the area of our study. Invasions that occur are classified into domestic, social and economic activity. The design concept is established on this flexibility hypothesis. The judgement criteria are made based on the main concepts mentioned above and are supported by theory.

\section{RESULT AND DISCUSSION}

The cultural-social issue of the problem of Medokkan Semampir Indah Tangkis residence is the existence of the phenomenon of spatial invasion in the context of their 


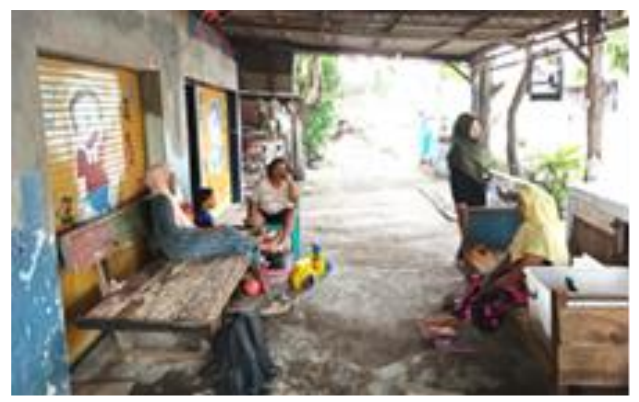

(a)

Figure 2. The atmosphere of

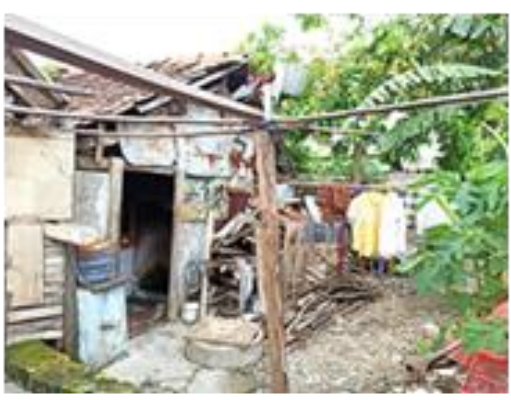

(b)

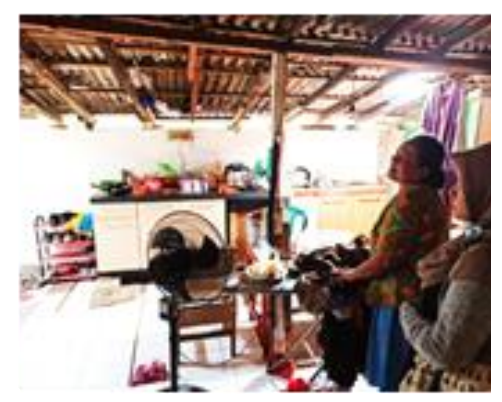

(c)

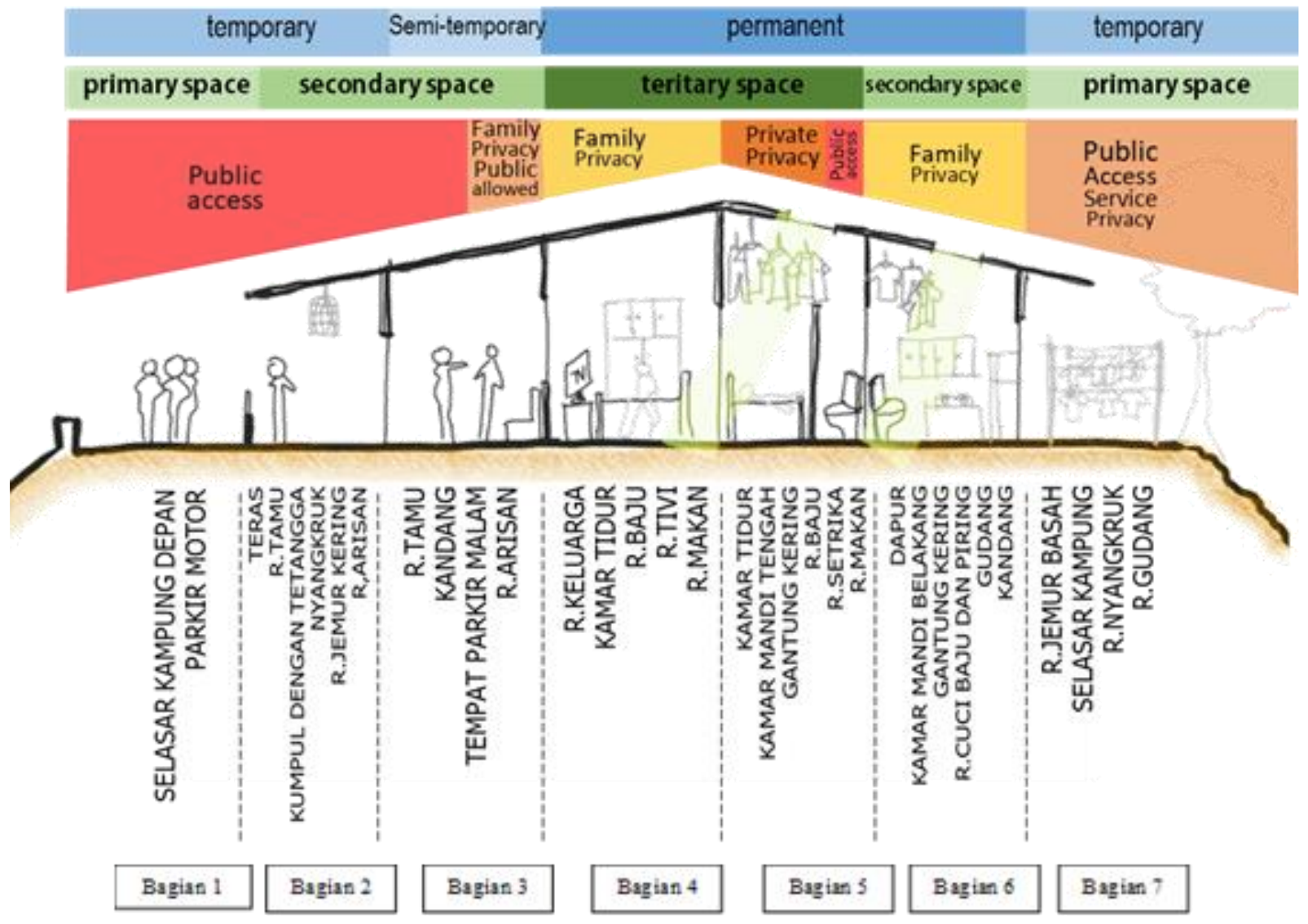

Figure 3. Mapping of territorial differences in the three domain.

settlements above the riverbanks. Our field study was conducted in the Medokan Semampir Indah Tangkis Surabaya riverbanks settlement, which had creative patterns and expressions towards space invasions. The space invasion of the inhabitants was expressed in domestic, social and economic activities.

The classification of community activities was divided by areas in the village. Based on village activities in the study, the area is divided into three domains, can seen in Figure 1. First is the Alley Domain or village road, this domain is an area that is defined differently - each of the residents. This area has village roads and terraces so One Citizen agreed to this area as their porch. At certain times it is also defined as a village road. Second is House domain, this area is an activity that occurs in all areas of the house. Third is the Riverbank domain.

\section{A. Alley Domain}

This area is the terrace area of the house which merges with the part of village road. The Economic activity can be seen in the form of physical invasion, where people put their working objects outside their residential area. Physical object should not be left out either permanently of temporarily. However, if there are carts or vehicles passing by, the residents of the terrace area will know it then open the way for the vehicles. Then they will rearrange the chairs for other activities. Other form of invasion is Social activity such as weekly social gathering of women, monthly social gathering for men, community discussion or also called nyangkruk (hang out). These activities occur spontaneously, using the area of invasion which is already prepared and acknowledged in advance. Domestic activity, for example hanging dry clothes is done outside the house, but hanging wet laundry tends to be hidden, either behind the house or in the front part of the house where it is well covered.

Domestic activity such as drying wet laundry or hanging dry clothes, where every resident has a space to hang wet laundry (dominantly outside) and a space to hang dry clothes 
The $6^{\text {th }}$ International Seminar on Science and Technology (ISST) 2020

July $25^{\text {th }} 2020$, Institut Teknologi Sepuluh Nopember, Surabaya, Indonesia

(inside/well-covered). The lack of space in the house and the amount of household items cause every family to have different place to put a clothesline. Drying wet clothes is done outside the house to get more wind and sunshine. After they are dried, they will be hung on different places before being fold. Some people hang them in the hallway of their house, some will hang them on the sheltered front terrace and some will hang them in the living room, close to the kitchen and dining room.

"I dry my laundry outside. When it is dried, I will move it to the back part (the back part of the house close to the river, but it is sheltered with additional roof)" (Mr. Kasur, 2020).

"I dry my laundry at the back, it is hotter there. If I hang it in the front side, I feel embarrassed as the other people can see it" (Mrs. Umar, 2020).

People tend to hide the activity of hanging wet laundry either in the front or back part, as long as it is covered. In reality, people feel ashamed to hang their clothes in an open space, but with limited space that they have, they end up drying the clothes outside.

Considering the other activity, such as social gathering of women, it is held every week in one of the residents' house in turn. Meanwhile the social gathering of men is held once every 2 weeks or once a month. These activities are constructive for each individuals and becoming awaited events in the village. This is the activity where all the residents in one neighbourhood could enter each other's residential areas. In addition, nyangkruk (hang out) or sitting around and having conversation together are often carried out in this village although there are only a few residents.

\section{B. House Domain}

Domestic activity of each house occurs due to the existence of only a space in the house where all activities are centred in one setting plot. That space becomes a multifunctional space, despite normally there is a specific space for each activities. Most often, some residents relaxing using the front room of the house. Some activities take place at the same space and it cannot be moved because of the existence of permanent household furniture. As a result in one space people do their cooking, dishes, showering, hanging dry clothes, ironing and storing clothes.

There are some criteria of the preferable space, that people like and this is the reason why their activities are focused on one or two points of the house. This space can be the living room where they are having conversation and spending most of their time. they are used to being in one space with a variety of possible activities, but not with a lot of furniture. For instance, the house of Mrs. Ida, their lives and activities are centred in a plot of shop space which is the part of outer house. Not only this space functioned as a shop, as their source of income, but also as the kitchen, dining room, study room, relaxing space, living room and playroom.

"The most activity is indeed in the front part of the shop. Here I cook, attend the customers, take a nap, watch TV, play with my kids and I also eat right here" (Mrs. Ida,2020).

But the question is, why they only need one space to do those activities? why is there barely any furniture in that one space where they do many activities? The answer is influence by several reasons, ranging from lack of space to do the activity, lack of fresh air, the amount of furniture, the variety of activity and communication between a number of individuals.

"Most often on the back part, it's brighter, cooler, I can do more activity" (Mrs. Ana, 2020).

"The river creates strong wind on the back part, it feels good. But since they had cut down the trees, now it becomes hot. It was nicer back then when the tree was still there" (Mrs. Ida, 2020).

"Not sure where I do my activities, eat and other things, could be anywhere. But the most frequent area is at the back. I only go inside the house to sleep. When I'm having guests, they usually prefer to be out here, they don't want to be inside" (Mr. Kasur, 2020).

Life in a plot in not just living in a space of the house. This experience is also related with the room layout and the interaction within it. Another example, Mrs. Ana house, which has one space where all the family member has to eat there. On the other hand, there are other activities which cannot be moved because of permanent furniture, such as the activity of cooking, washing dishes and taking a shower are carried out in one space. Hanging dry clothes, ironing and storing clothes also take place within the same space. Therefore, from the explanation above, we can understand how each participant gives the meaning of the house, which consist of the experience, the ambience and the memory that occurs. The river also gives indirect influence which affect the mapping of activities and spatial planning. Participant feels comfortable and accustomed to a life in a single space plot with variety of activities and functions. Figure 2(a), Figure 2(b), and Figure 2(c) show the atmosphere of the space in alley domain, riverbank domain, and housing domain, respectively.

\section{Riverbanks Domain}

The context of riverbanks influence the perceptual difference especially on the area of the back of the house. Residents of Medokan Tangkis have different perception about the front and the back of the house. some consider that the front part is the part facing the main road, while the other consider that the part facing the river is the front part of the house. This difference is based on three factors, which are the road condition, the cleanliness and the utilisation of the front and back part of the house. The house that is considered as facing front is the one facing the river. On the other hand, some houses are located where the river is in the form of dirt, mud, dust and grass. For houses with this condition, they assume that the front part of the house is the one facing the road. As a result, the house with a good back passage condition, which is close to the river, will use that part to hang the laundry. In contrary, the house with an unacceptable/damaged back passage will prefer to hang the laundry in the front part of the terrace. As for the social activity, participants don't prefer to live in a place where they can see directly to their neighbour's house. They need gap/space between activities and privacy when they are relaxing in front of the house. 
The $6^{\text {th }}$ International Seminar on Science and Technology (ISST) 2020

July $25^{\text {th }} 2020$, Institut Teknologi Sepuluh Nopember, Surabaya, Indonesia

Most of the layout for the front and back part of the house are very spacious and clean (the warehouse is scattered inside the house). There is lighting on the roof - a long space program (to save electricity). Participants have tendency not to live where they can see directly to the front part of their neighbour's house, but they like to stay in front of the house. One of the unique habits of the residents is that they do not always want to interact when sitting outside the house, but they often and like to sit there just because it is stuffy inside the house.

"If you live in a flat, normally our activities which we do in private, become public attractions. It doesn't feel right, it's uncomfortable” (Mrs. Ida, 2020).

"I don't like living right in front of other people. It doesn't feel comfortable when you open your door and the first thing you see directly is that other person" (Mrs. Ana, 2020).

Physical invasion is found different for each resident. This is influenced by the length of the village, occupation of the residents, the relationship between residents, and the duration of use of the house. This difference can be classified into some areas that were previously divided. Every area in this village has a perception and response to physical invasion of space. There were different responses regarding the space whether of the front or of the back, for example, they gave different answers when they were asked about the same question: "do you think in this area, either you or your neighbour physically invade each other's house area such as leaving belongings or holding events?" and the next question is "if the answer is yes, how would the rest of the residents response to it?"

"In this area sometimes, it is not allowed to leave your belongings in front of someone else's house or even around others' area. Well you know it, it is a community agreement" (Mrs. Ana, 2020).

On the first area, it is forbidden to leave or deposit belongings in the area of other people's house. This is a form of indirect agreement between the residents. The feeling of ashamed and embarrassment are also become triggers to reach this agreement (domestic activity). The residents of this area also respect other resident by not psychologically disturbing by the noise and smell. As a concrete example which is done by Mr. Sukar, that he always put some music on with his sound system during the day, but not during the night. However, among all the residents, Mr. Sukar is one that gets disturbed if there is a neighbour who held an event, despite asking for permission in advance (domestic activity).

"Sometimes if there is an event, I am actually disturbed. But what can I do. Well I'm aware that it's the villagers' event. I have to keep my mouth and behave so that people won't scold me" (Mr. Kasur, 2020).

"Well in our own house, you know. If it is in front of our neighbours' house it will be disturbing. But if you want to leave your belongings there, it's okay as long as it's only for short period of time and with the permission. The point is if you want to place your things, it shouldn't block the way or annoy the people passing by" (Mrs. Sati, 2020).

On the second area, it is also not allowed to leave belongings, but there is a few who does it anyway at a certain time. Their mutual agreement is to leave belongings in their own house. But if there is someone who put or leave his belongings within the area of other people's house, the resident will tolerate it well as long as it doesn't affect or disturb the road (domestic activity).

Physical invasion also occurs socially and it is different in each housing area. Social activity appears in the form of as weekly gathering of women, monthly gathering of men, daily hang out of residents and incidental events such as wedding, or death of neighbours. On the first area, the most frequent event is recitation which is done within this area because of the proximity with the mosque which is located by the end of the street. The invasion occurs by the children who are sitting around in front of the house. The residents feel that it is normal and the don't feel disturbed by it. If there is a deceased person then people do a recital ceremony in the mosque, then there will be some family members who will sit in front of other's house and this is acceptable by the residents (social activity). On the second area, residents in this area rarely involved in the physical invasion. They only do activity such as gossiping/ hang out when there is no work while they can also enjoy the breeze in front of the house (social activity).

"No, I don't place my belongings around. There is a lot of people passing by, and they can pass through as they like. When they do, we can put the chair aside for a moment" (Mrs. Nemi, 2020).

On the third area, physical invasion happens in the form of social gathering activity. It is not frequently happened, but some houses accommodate it by arranging some chairs in front of the house and anyone can use them freely (social activity). In this area, when there is an event, residents will definitely ask for permission to their neighbours, which is a polite habit among them. Figure 3 show the mapping of territorial differences in the three domain (Author Illustration based on the explanation from Kopec, 2006).

Invasion on the research area also influence territory and privacy. The most private area in a residential area is the teritary space where there is individual and family privacy. However, in a certain social activity period, the teritary space will allow some public activities to be held there. In contrary, the secondary space in the front part of the house, at a certain time, will be teritary space where the family private activity takes place. Based on the activity and social activity carried out at certain times, the private space on area 2,3,4 and 7 will not be private anymore, even though those area should be private spaces. This fact showed that social activity and some of domestic activity can cause a shift from private to nonprivate space at a certain time in the same setting.

The result of the discussion above combined with the factual events happened during the field observation are used to establish the conceptual priorities:

Neighbour view to house aperture: the point of view of neighbour/ residents around towards aperture of the house.

1. Interactive room: a room used to interact according to the activity carried out. To accommodate changes of residence activity due to its development.

2. Flexible Activity: the expression of space invasion defined as an eventual invasion of space. Flexible activity among residents and houses will create a time-based space. 
The $6^{\text {th }}$ International Seminar on Science and Technology (ISST) 2020

July $25^{\text {th }} 2020$, Institut Teknologi Sepuluh Nopember, Surabaya, Indonesia

3. Flexible Partition: to create partition between spaces which is flexible and changeable.

4. Open space and shade: an open space to accommodate the other four priorities, but also providing shade/shelter for activities to be carried out there.

Based on the activities obtained during the field study, resulting that the space invasion, then the precedent of Rusunawa and flexibility concept referred here, the author has determined four judgement criteria or special criteria. These criteria will be used to explore the five of architectural concepts, which are eventual space, not private privacy, and one for all first, as the three main concepts, while the other two proposed moment are classified as supporting factors.

\section{1) Eventual Space}

Invasion space which appears eventually as a space related to the residential life, service, village activities and neighbours' activities. This concept is a moment of messo to macro, which means that the moment is able to affect the relationship between the flat until the relationship between the building.

\section{2) The Unprivate Privacy}

Privacy which is not private, meaning that the privacy of inhabitants at a certain time which can be seen, felt and accessed by the public. This concept describes a vague boundary between some activities inside the house and public activities.

\section{3) One for All}

One space/ setting to accommodate several activities at different times. That space will be defined as the time changes. One setting can be converted into various meanings of space. This concept is a micro invasion, which generates a relationship within a flat.

\section{4) Interlacing (Daylight-Airing) Nature For Privacy}

Natural factor influences privacy of various spaces and design aperture. This concept considers the nature as a constraint in designing.

\section{5) Space Quality Based on Human Comfort Quality}

Human comfort factor becomes the main consideration in designing a space.

\section{CONCLUSION}

Space Invasion in the context of riverbanks consist of some criteria. First of all, participants preferred an open space design which provides flexibility in doing their activities and also allows the breeze to enter, but they also put a limitation to the outside view. This criteria proved the theory of Kopec and Alan (2018), with the fact that the residents of illegal area want a housing arrangement according to the adaptation of their life style, and in this context referring an adaptation towards apertures/openings. The second point is that the spatial invasion involves a variety of activities, and also a lot of time in one setting, therefore this criteria support the study of Lianto and Dwisusanto (2015). The third point, illegal invasion is always based on an oral/direct legal agreement. This criteria gives a different point of view towards the definition of invasion according to KBBI (Great Dictionary of the Indonesian Language of the Language Centre, 2019) which is define as a matter or act of entering another territory with the intention of attacking or controlling the targeted area. This criteria also supports the study carried out by Lianto and Dwisusanto (2015) that in the life of either horizontal or vertical settlements, especially the simple, low-cost apartment buildings, which frequently occurs territorial violation and take over/ conflict on the specific area with territorial boundaries. This type of act can be done either by pure unintentionally, mutual agreement or with certain agreements. The fourth point is that the spatial invasion creates a gap of a setting with the activity, so that activities that occur are only the ones that are needed. At a certain time, the activity can be done simultaneously in conjunction with the other activity or involving the other furniture. This criteria supports and proves the theory of Kronenburg (2007), that the flexibility can be seen as an interaction with its users, as innovative and expressive interaction of contemporary design. Additionally, there were more different expressions of the residents along the riverbanks. First, they made flexible of their house element to accommodate and fulfil their activities. This criterion is in accordance to the study carried out by Frick and Mulyani (2006), mentioning that the growth such as adaptation towards the changes in life. Second, they kept their privacy within the privacy discretion which applies in the village around them, whether on the terrace in front of the village or the terrace on the riverbanks side. This criteria supports the study carried out by Lianto, Dwisusanto (2015) which stated that in a certain condition, inhabitants of a simple low-cost apartment can appreciate and respect the territorial boundaries even though there was no clear physical boundary, they showed a great act of tolerance. The result of this study can be used as a contribution to provide criteria and design parameter according to the needs and desires of the users. In the future, it can be used as a main idea or main force and also a customised design concept to design a simple, lowcost apartment buildings/ Rusunawa.

\section{ACKNOWLEDGEMENT}

This paper is a part of master's thesis research and supported in part by Master Thesis Research Grant Year 2020 funded by Deputi Bidang Penguatan Riset dan Pengembangan Kementerian Riset dan Teknologi/Badan Riset dan Inovasi Nasional.

\section{REFERENCES}

[1] Cetkovic Alexander (2012). Flexibility in architecture and its relevance for the ubiquitous house. Technoetic Arts: A Journal of Speculative Research Volume 10 Numbers 2 \& 3. University of Plymouth. England.

[2] Creswell, John (2014) Research Design: Qualitative, Quantitative and Mixed Methods Approaches. SAGE Publications, Inc; 4th edition.

[3] Das, A. (2017). A City of Two Tales: Shelter and Migrants in Surabaya. Environment and Urbanization ASIA, 21

[4] Das, A. (2015). Slum upgrading with community-managed microfinance: Towards progressive planning in Indonesia. Habitat International, 47, 256-266. doi:https://doi.org/10.1016/j.habitatint. 2015.01.004

[5] Frick Heinz, Mulyani Tri Hesti (2006) Arsitektur Ekologis : Konsep arsitektur ekologis pada iklim tropis, penghijauan kota dan kota 
The $6^{\text {th }}$ International Seminar on Science and Technology (ISST) 2020

July $25^{\text {th }} 2020$, Institut Teknologi Sepuluh Nopember, Surabaya, Indonesia

ekologis, serta energi terbarukan. Seri Eko-Arsitektur 2, Kanisius, Yogyakarta.

[6] Haryadi B. Setiawan. (2010), Arsitektur Lingkungan dan Perilaku, Gadjah Mada University Press.

[7] Hutagalung, A. S. (2004). Dinamika Pengaturan Rumah Susun atau Apartemen. Hukum dan Pembangunan, 34 doi:http://dx.doi.org/10.21143/jhp.vol34.no4.1443.

[8] Jormakka (2007) Basics Design Methods, Birkhäuser Architecture; 1 edition.

[9] Kopec, D., \& Alan, D. (2018). Environmental Psychology for Design, 3rd Edition. 1385 Broadway New York: Bloomsbury Publishing Inc.

[10] Kronenburg Robert (2007). Flexible: Architecture that Responds to Change by Robert Kronenburg. Laurence King. ASIN: B01F81UGOK.
[11] Lianto. F, Dwisusanto. B (2015) Teritorialitas Dan Keamanan Penghuni Pada Permukiman Horisontal Dan Vertikal (Rumah Susun Sederhana) (Studi Kasus : Rumah Susun Sederhana Sewa (Rusunawa) Bumi Cengkareng Indah, Jakarta). Jurnal Sosek Pekerjaan Umum, Vol.7 No.3, hal $219-227$

[12] Maslow, A. and Lowery, R. (Ed.) (1998). Toward a psychology of being. 3rd Edition, Wiley \& Sons, Hoboken.

[13] Plomp Tjeerd, Nieveen Nienke (2007) An Introduction to Educational Design Research. Proceedings of the seminar conducted at the East China Normal University, Shanghai (PR China), November 23-26, 2007. SLO, Netherlands institute for curriculum development.

[14] Rapoport, A. (2005). Culture, Architecture and Design. Chicago, Locke Science Publishing Co., Inc. 